\title{
PENGARUH EKSTRAK LIDAH BUAYA (Aloe vera L.) TERHADAP PERTUMBUHAN Candida albicans PADA BASIS GIGI TIRUAN RESIN AKRILIK HEAT CURED
}

\author{
Pocut Aya Sofya*, Liana Rahmayani*, Zaza Yunda Putri* \\ *Fakultas Kedokteran Gigi Universitas Syiah Kuala, Aceh \\ Korespondensi: pocutayasofya@yahoo.com
}

\begin{abstract}
ABSTRAK
Latar belakang: Candida albicans dapat berpenetrasi pada resin akrilik dan berkembang biak pada gigi tiruan sehingga dapat menginfeksi jaringan lunak yang menyebabkan denture stomatitis. Lidah buaya (Aloe vera $L$.) memiliki sifat anti jamur yang menurut penelitian efektif untuk menghambat pertumbuhan Candida albicans. Tujuan: penelitian ini bertujuan untuk menjelaskan pengaruh lidah buaya (Aloe vera L.) sebagai pembersih gigi tiruan terhadap jumlah Candida albicans pada basis gigi tiruan resin akrilik heat cured. Metode: subjek penelitian diinkubasi dalam suspensi Candida albicans selama 24 jam pada suhu $37^{\circ} \mathrm{C}$. Subjek penelitian berupa lempeng akrilik dibagi menjadi 3 kelompok yaitu kelompok yang direndam dalam ekstrak lidah buaya (Aloe vera L.) konsentrasi $75 \%, 100 \%$ dan akuades sebagai kelompok kontrol. Setelah diberi perlakuan, spesimen tersebut dimasukkan ke dalam tabung reaksi yang berisi $\mathrm{NaCl} 0,9 \% 10 \mathrm{ml}$ dan digetarkan dengan vortex selama 30 detik, kemudian $0,1 \mathrm{ml}$ dari larutan tersebut dibenihkan ke dalam Sabouraud Dextrose Agar. Analisis data menggunakan uji Kruskal-Wallis dan Mann-Whitney. Hasil: penelitian ini menunjukkan bahwa ekstrak lidah buaya (Aloe vera L.) konsentrasi $75 \%$ dan $100 \%$ dapat menghambat pertumbuhan Candida albicans. Kesimpulan: berdasarkan pernyataan tersebut, maka terdapat pengaruh ekstrak lidah buaya (Aloe vera L.) sebagai pembersih gigi tiruan terhadap pengurangan jumlah Candida albicans pada basis gigi tiruan resin akrilik heat cured.
\end{abstract}

Kata kunci: basis gigi tiruan, Candida albicans, Lidah Buaya (Aloe vera L.)

\begin{abstract}
Background: Candida albicans can penetrate acrylic resin and will grow on artificial teeth so that it can infect soft tissue and cause denture stomatitis. Aloe vera has anti-fungal properties which according to research are effective in inhibiting the growth of Candida albicans. Purpose: this study aims to explain the effect of aloe vera as a denture cleaner on the number of Candida albicans on heat-cured acrylic resin denture base. Method: subjects were incubated in a Candida albicans suspension for 24 hours at $37^{\circ} \mathrm{C}$. Research subjects in the form of acrylic plates were divided into 3 groups, each group immersed in aloe vera extract with a concentration of $75 \%, 100 \%$, and distilled water as a control group. After being treated, the specimen was put into a test tube containing $0.9 \% \mathrm{NaCl} 10 \mathrm{ml}$ and vibrated with vortex for 30 seconds, then $0.1 \mathrm{ml}$ of the solution was seeded into Sabouraud Dextrose Agar. Data were analyzed using the Kruskal-Wallis and Mann-Whitney tests. Result: the results of this study indicated that $75 \%$ and $100 \%$ concentration of aloe vera extract could inhibit the growth of Candida albicans. Conclusion: based on this statement, there was an effect of aloe vera extract as a denture cleaner on reducing the number of Candida albicans on the base of the heat-cured acrylic resin denture.
\end{abstract}

Keywords: denture base, Candida albicans, Aloe Vera

\section{PENDAHULUAN}

$\mathrm{R}$ esin akrilik merupakan bahan basis gigi tiruan yang sering digunakan sampai saat ini karena memiliki sifat yang tidak toksik, estetik yang baik, harga yang relatif murah, mudah direparasi, serta mudah dalam manipulasi dan pembuatannya. ${ }^{1}$ Resin akrilik terdiri dari campuran bubuk (polimer) dan cairan (monomer) dengan perbandingan yang tepat. ${ }^{2}$

Resin akrilik (heat cured) merupakan salah satu bahan basis gigi tiruan resin akrilik yang polimerisasinya dengan pengaplikasian panas. $^{3}$ Basis gigi tiruan resin akrilik mempunyai sifat porus 
disebabkan oleh pori-pori yang banyak serta dapat menyerap cairan di rongga mulut. Sifat ini dapat dengan mudah menyebabkan akumulasi sisa makanan dan plak yang nantinya akan berdampak terhadap kesehatan jaringan mukosa yang berada di bawah gigi tiruan. ${ }^{4}$ Candida albicans dapat melekat pada resin akrilik dan akan tumbuh pada gigi tiruan sehingga dapat menginfeksi jaringan lunak dan menyebabkan denture stomatitis. ${ }^{5}$

Candida merupakan spesies jamur yang umumnya ditemukan di rongga mulut yang sehat dan merupakan $25 \%$ sampai $50 \%$ dari mikroflora normal di rongga mulut. Spesies Candida yang paling umum ditemukan di rongga mulut manusia adalah Candida albicans. Pada resin akrilik, spesies Candida yang paling umum diisolasi adalah Candida albicans (78\%), Candida glabrata (44\%), dan Candida tropicalis (19\%). ${ }^{6}$ Candida albicans dapat menyebabkan terjadinya infeksi apabila terdapat faktor predisposisinya, salah satunya apabila terjadi iritasi kronis pada jaringan setempat. Permukaan gigi tiruan resin akrilik bersifat kasar, serta terdapat porositas yang dapat mendukung terjadinya iritasi klinis pada mukosa di bawah basis gigi tiruan resin akrilik. Hal ini dapat bertambah parah jika kebersihan rongga mulut kurang baik sehingga terjadi penumpukan plak dan akan menyebabkan inflamasi yang bersifat kronis sampai terjadi denture stomatitis. $^{4}$

Pembersihan gigi tiruan dengan merendam basis gigi tiruan menggunakan bahan pembersih gigi tiruan bertujuan untuk menghindari adanya kontaminasi dari bakteri dan jamur. ${ }^{5}$ Lidah buaya (Aloe vera $L$.) memiliki sifat anti jamur yang menurut penelitian efektif untuk menghambat pertumbuhan Candida albicans. ${ }^{7}$

Berdasarkan formularium ramuan obat Tradisional Indonesia oleh Menteri Kesehatan Republik Indonesia tahun 2017 menyatakan Lidah buaya (Aloe vera $L$.) termasuk dalam daftar tanaman obat tradisional yang mudah diperoleh. ${ }^{8}$ Lidah buaya (Aloe vera L.) memiliki efek antimikroba yang resisten terhadap mikroorganisme pada pulpa. Lidah buaya (Aloe vera L.) mengandung zat antiseptik seperti lupeol, asam salisilat, nitrogen urea, asam sinamat, fenol, dan sulfur yang dapat menghambat pertumbuhan dari jamur, bakteri, dan virus. ${ }^{9}$ Lidah buaya (Aloe vera L.) juga mengandung zat aloemoedin dan aloebarbadiod yang termasuk dalam golongan antrakuinon yang bersifat sebagai anti jamur. ${ }^{7}$

Sadimin, dkk (2015) menyatakan bahwa getah lidah buaya (Aloe vera L.) pada konsentrasi $50 \%, 75 \%$ dan $100 \%$ memiliki daya hambat terhadap pertumbuhan bakteri Sterptococcus mutans. ${ }^{10}$ Huslina, Feizia (2017) menyatakan bahwa ekstrak daun lidah buaya (Aloe veta L.) dengan konsentrasi $25 \%, 50 \%$ dan $100 \%$ memiliki daya hambat terhadap pertumbuhan Candida albicans secara in vitro. ${ }^{7}$ Semakin tinggi konsentrasi yang digunakan, maka semakin besar daya hambat yang dihasilkan oleh getah lidah buaya tersebut. ${ }^{10}$

Sampai saat ini informasi mengenai pengaruh penggunaan lidah buaya (Aloe vera L.) sebagai bahan alternatif pembersih gigi tiruan yang dapat menghambat pertumbuhan Candida albicans masih terbatas sehingga penelitian ini dilakukan.

\section{METODE PENELITIAN}

Pembuatan spesimen dilakukan di Laboratorium PCP dental Lab. Pembuatan ekstrak lidah buaya (Aloe vera L.) dilakukan di Laboratorium Farmakologi Fakultas Kedokteran Hewan Universitas Syiah Kuala. Perlakuan terhadap spesimen dan perhitungan jumlah koloni Candida albicans dilakukan di Fundamental Laboratorium Sains pada bulan 27 Januari sampai 31 Januari 2020.

\section{Pembuatan Spesimen Resin Akrilik Heat Cured}

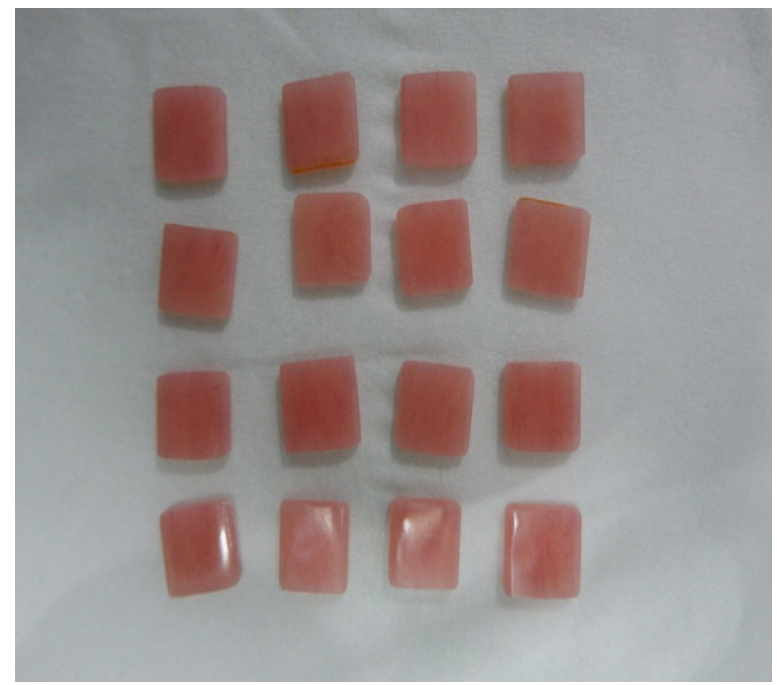

Gambar 1. Spesimen resin akrilik heat cured

Tahap pengolahan (packing) akrilik dilakukan dengan cara: permukaan mould space diolesi dengan Cold Mold Seal (CMS) dengan menggunakan kuas dan tunggu hingga mengering. Kemudian disiapkan cawan porselen yang diisi dengan perbandingan 23 mg: $10 \mathrm{ml}$ dari polimer dan monomer. Kemudian dimasukkan bubuk polimer sedikit demi sedikit sambil menggetarkan cawan sampai adonan terlihat seperti pasir basah. Bubuk polimer dimasukkan sampai tidak ada kelebihan dari monomer. Apabila adonan sudah mencapai tahap dough stage, seluruh adonan diambil dengan menggunakan spatula dan dimasukkan ke dalam mould space. Kemudian permukaannya dilapisi oleh plastik cellophane. Kemudian kuvet atas dipasangkan kembali beserta dengan tutupnya dan dilakukan pengepresan yang ringan. Kuvet kembali dibuka dan 
dibuang kelebihan adonan. Hal ini dilakukan beberapa kali sampai kuvet metal to metal. Jika tidak ada lagi kelebihan akrilik, plastik cellophane dibuka kemudian sekrup dipasang dan dilakukan pengepresan akhir dengan alat press. ${ }^{11}$

Tahap pemasakan akrilik (curing) dilakukan dengan cara dipanaskan dalam air kurang lebih $100^{\circ} \mathrm{C}$ selama 45 menit. Tahap selanjutnya adalah mengeluarkan model akrilik dari dalam kuvet (deflasking), berikutnya salah satu bagian spesimen dihaluskan dengan menggunakan amplas No. 240, 400, dan 1000 sampai permukaan rata dengan ukurannya 10 × 10 × 2 mm sebanyak 27 buah. ${ }^{11}$ Spesimen yang sudah jadi direndam dalam gelas berisi $30 \mathrm{ml}$ akuades pada suhu $25^{\circ} \mathrm{C}$ selama 24 jam untuk menghilangkan sisa monomer. ${ }^{11}$

\section{Ekstraksi Lidah Buaya (Aloe vera L.) 75\% dan 100\%}

Ekstrak lidah buaya (Aloe vera $L$.) didapatkan dengan cara membelah daun lidah buaya tersebut untuk diambil dagingnya yang kemudian akan dicampurkan dengan air. ${ }^{10}$

a. Ekstrak Lidah buaya $75 \%$

Digunakan 75 gr lidah buaya dicampurkan dengan $25 \mathrm{ml}$ air untuk menghasilkan ekstrak lidah buaya $75 \%$.

b. Ekstrak Lidah buaya $100 \%$

Digunakan 100 gr lidah buaya untuk menghasilkan ekstrak lidah buaya $100 \% .^{10}$

\section{Pembuatan Media Sabouraud Dextrose Agar}

Sebelum spesimen dibiakkan terlebih dahulu dilakukan pembuatan media. Untuk kultur jamur dibuat media Sabouraud Dextrose Agar (SDA). Media agar yang digunakan dibuat dengan mencampurkan bubuk media Sabouraud Dextrose Agar (SDA) sebanyak 6,5 gram dengan air suling steril lalu dipanaskan sampai larut kemudian dibungkus dengan alumunium foil dan disterilkan dalam autoklaf pada suhu $121^{\circ} \mathrm{C}$ selama 15 menit. Tuangkan ke cawan petri dan dibiarkan sampai dingin dan mengeras. ${ }^{12}$

\section{Pembuatan Suspensi Candida albicans}

Diambil satu mata ose biakan jamur Candida albicans yang berumur 24 jam, kemudian dicampurkan ke dalam tabung reaksi yang berisi cairan $\mathrm{NaCl} 0,9 \%$ sebanyak $10 \mathrm{ml}$. Suspensi jamur dihomogenkan dengan divortex selama lebih kurang 15 detik, lalu dituangkan ke dalam tabung reaksi sebanyak $7 \mathrm{ml}$. Tabung reaksi dimasukkan ke dalam spektrofotometer kemudian dibandingkan tingkat kekeruhan dengan larutan standard Mc Farland 0,5 yang setara dengan $1,5 \times 10^{8} \mathrm{CFU} / \mathrm{ml}^{13}$

\section{Cara Perendaman}

Sebanyak 27 buah sampel berupa lempeng akrilik dimasukkan ke dalam tabung reaksi berisi suspensi Candida albicans sesuai dengan standard Mc Farland $\left(1,5 \times 10^{8} \mathrm{CFU} / \mathrm{ml}\right)$ selama 24 jam dengan suhu $37^{\circ} \mathrm{C}$. Kemudian sampel direndam dalam vial yang dibagi menjadi 3 kelompok dengan masingmasing memiliki 9 sampel. Kelompok 1 direndam dalam larutan ekstrak lidah buaya (Aloe vera L.) 75 $\%$, kelompok 2 direndam dalam larutan ekstrak lidah buaya (Aloe vera L.) $100 \%$, dan kelompok 3 direndam dalam larutan akuades (kontrol). Perendaman dilakukan selama 8 jam yang diasumsikan sebagai perendaman gigi tiruan pada waktu istirahat malam hari. ${ }^{14}$

\section{Prosedur Perhitungan Jumlah Koloni Candida albicans}

Perhitungan jumlah koloni Candida albicans dilakukan setelah perendaman. Spesimen dikeluarkan dari vial, kemudian dibilas dengan menggunakan Phosphatase Buffered Saline (PBS), setelah itu dimasukkan ke dalam $10 \mathrm{ml} \mathrm{NaCL} 0,9 \%$ dan divibrasi dengan vortex selama kurang lebih 30 detik dengan tujuan merontokkan Candida albicans. Kemudian, $0,1 \mathrm{ml}$ hasil dari vortex dibenihkan dalam Sabouraud Dextrose Agar, dan diinkubasi selama 48 jam dengan suhu $37^{\circ} \mathrm{C}$. Kemudian perhitungan koloni Candida albicans dilakukan dengan metode perhitungan pada colony counter. ${ }^{14}$

\section{Analisis Data}

Data dikumpulkan melalui uji laboratorium. Hasil data penelitian ini diolah dan dianalisis dengan menggunakan uji Kruskal-Wallis, kemudian dilakukan Mann-Whitney sebagai uji lanjutan.

\section{HASIL PENELITIAN}

Tabel 1 menunjukkan bahwa ekstrak lidah buaya (Aloe vera L.) pada konsentrasi $75 \%$ memiliki jumlah rata-rata koloni 182,11 CFU/ml, pada konsentrasi $100 \%$ memiliki jumlah rata-rata koloni 104,22 CFU/ml, dan pada kelompok kontrol akuades memiliki jumlah rata-rata koloni sebesar 278,22 CFU/ $\mathrm{ml}$. 
Tabel 1. Jumlah rata-rata koloni Candida albicans pada resin Akrilik Heat Cured setelah diuji dengan ekstrak Lidah Buaya (Aloe vera L.)

\begin{tabular}{cccccccccccc}
\hline \multirow{2}{*}{ Konsentrasi Bahan Uji } & \multicolumn{10}{c}{ Jumlah Koloni (CFU/ml) } & \multicolumn{2}{c}{$\begin{array}{c}\text { Jumlah Rata-rata } \\
\text { Koloni (CFU/ml) }\end{array}$} \\
\cline { 2 - 9 } & 1 & 2 & 3 & 4 & 5 & 6 & 7 & 8 & 9 & 182,11 \\
\hline $75 \%$ & 220 & 202 & 200 & 192 & 184 & 175 & 164 & 152 & 150 & 104,22 \\
\hline $100 \%$ & 148 & 130 & 136 & 120 & 114 & 98 & 76 & 66 & 50 & 278,22 \\
\hline
\end{tabular}

Keterangan: $\mathrm{CFU}=$ Colony Forming Unit per milliliter

Tabel 2. Hasil uji Kruskal-Wallis

\begin{tabular}{lr}
\hline & Jumlah Koloni \\
\hline Chi-Square & 23.143 \\
Df & 2 \\
Asymp. Sig. & $.000^{*}$ \\
\hline *Uji Kruskal-Wallis (signifikan $\mathrm{p}<0,05)$ &
\end{tabular}

Tabel 3. Hasil Uji Mann-Whitney kelompok ekstrak Lidah Buaya (Aloe vera L.) 75\% dengan akuades dan kelompok ekstrak Lidah Buaya (Aloe vera L.) 100\% dengan akuades

\begin{tabular}{lr}
\hline & Jumlah Koloni \\
\hline Mann-Whitney U & .000 \\
Wilcoxon W & 45.000 \\
Z & -3.576 \\
Asymp. Sig. (2-tailed) & .000 \\
Exact Sig. [2*(1-tailed Sig.)] & $.000^{\mathrm{b}}$ \\
\hline
\end{tabular}

Tabel 2 menunjukkan hasil uji statistik dengan Kruskal-Wallis diperoleh hasil yang signifikan $(\mathrm{p}=0,000)$. Nilai $\mathrm{p}$ ini menunjukkan adanya pengaruh yang bermakna $(\mathrm{p}<0,05)$ dari ekstrak lidah buaya (Aloe vera L.) konsentrasi $75 \%$ dan $100 \%$ dalam menghambat pertumbuhan Candida albicans.

Tabel 3 menunjukkan hasil uji statistik dengan Mann-Whitney diperoleh hasil yang menunjukkan adanya pengaruh yang signifikan semua pasangan perlakuan terhadap jumlah koloni Candida albicans pada basis gigi tiruan resin akrilik heat cured dengan nilai signifikan $(\mathrm{p}<0,05)$.

\section{PEMBAHASAN}

Candida albicans termasuk flora normal rongga mulut dan mempunyai sifat patogen oportunistik. Candida albicans dalam keadaan normal tidak menimbulkan kelainan, sifat patogen timbul pada situasi tertentu yang pada umumnya berhubungan dengan gangguan keseimbangan flora normal rongga mulut. Basis gigi tiruan dapat meningkatkan populasi Candida albicans karena kemampuan Candida albicans untuk melekat pada permukaan benda padat seperti basis gigi tiruan yang dilapisi oleh pelikel yang terdiri dari protein saliva dan serum yang menjadi reseptor bagi perlekatan mikroorganisme salah satunya Candida albicans. ${ }^{15}$ Candida albicans yang melekat pada permukaan basis gigi tiruan resin akrilik heat cured dapat mengakibatkan terjadinya denture stomatitis pada pemakai gigi tiruan tersebut. ${ }^{5}$ Denture stomatitis merupakan suatu reaksi peradangan yang terjadi pada jaringan lunak pendukung gigi tiruan. Faktor predisposisi yang berperan pada denture stomatitis antara lain candida albicans, trauma akibat gigi tiruan, kebersihan gigi tiruan, pemakaian gigi tiruan yang terus menerus, kesehatan mulut, kondisi sistemik dan nutrisi serta peranan saliva. ${ }^{2}$

Penelitian ini bertujuan untuk menjelaskan adanya pengaruh ekstrak lidah buaya (Aloe vera L.) terhadap pertumbuhan Candida albicans pada basis gigi tiruan resin akrilik heat cured. Penelitian ini menggunakan resin akrilik heat cured yang memiliki kekurangan mempunyai pori-pori mikro sehingga memudahkan sisa makanan dan bakteri untuk masuk kedalamnya. ${ }^{16}$ Lama waktu perendaman spesimen dalam ekstrak lidah buaya (Aloe vera L.) 8 jam untuk setiap kelompok perlakuan yang diasumsikan gigi tiruan akan direndam dalam air saat malam hari. ${ }^{14}$

Pembuatan ekstrak lidah buaya (Aloe vera L.) pada penelitian ini menggunakan metode ekstraksi dengan pencampuran langsung antara lidah buaya 
(Aloe vera L.) dengan akuades. Selain metode ini, ada metode lain yang dapat digunakan dalam pembuatan ekstrak. Salah satunya adalah metode maserasi yang pernah digunakan dalam beberapa penelitian lainnya. ${ }^{17}$

Tabel 1 menunjukkan hasil perhitungan jumlah koloni Candida albicans pada resin akrilik heat cured sesudah dilakukan perendaman dengan ekstrak lidah buaya (Aloe vera L.) dan akuades sebagai kontrol. Hasilnya menunjukkan bahwa ekstrak lidah buaya (Aloe vera L.) memiliki pengaruh terhadap pertumbuhan Candida albicans pada basis gigi tiruan resin akrilik heat cured. Jumlah koloni Candida albicans yang digunakan berdasarkan standard Mc Farland 0,5 yang setara dengan $1,5 \times 10^{8} \mathrm{CFU} / \mathrm{ml}$. Ekstrak lidah buaya (Aloe vera L.) konsentrasi $75 \%$ menunjukkan jumlah rata-rata koloni yang tumbuh sebanyak 182,11 CFU/ml, ekstrak lidah buaya (Aloe vera L.) konsentrasi $100 \%$ jumlah koloni rata-rata adalah 104,22 CFU/ml, dan kelompok dengan akuades jumlah koloni rata-rata sebesar 278.22 CFU/ml. Hasil tersebut menunjukkan bahwa jumlah koloni Candida albicans terkecil terdapat pada ekstrak lidah buaya (Aloe vera L.) dengan konsentrasi 100\% sedangkan jumlah koloni Candida albicans terbesar terdapat pada kelompok dengan akuades.

Hasil penelitian ini menunjukkan bahwa jumlah koloni Candida albicans mengalami penurunan seiring dengan meningkatnya konsentrasi ekstrak lidah buaya (Aloe vera L.). Hal ini diduga karena terdapatnya kandungan antifungal dalam ekstrak lidah buaya (Aloe vera $L$.) dimana semakin besar konsentrasi ekstrak lidah buaya (Aloe vera L.) digunakan, maka semakin besar pula daya hambat yang dihasilkan untuk menghambat pertumbuhan Candida albicans. Hal ini sejalan dengan penelitian Sadimin, dkk (2015) yang menyatakan bahwa semakin tinggi konsentrasi yang digunakan, maka semakin besar daya hambat yang dihasilkan oleh lidah buaya tersebut. ${ }^{10}$

Tabel 2 menunjukkan hasil analisis statistik menggunakan uji Kruskal-Wallis pada perhitungan jumlah koloni Candida albicans yang menunjukkan adanya perbedaan signifikan antara jumlah rata-rata pada koloni setiap kelompok perlakuan yang ditandai dengan nilai signifikan $(\mathrm{p}=0,000)$. Hasil tersebut dapat dilihat bahwa terdapat perbedaan yang bermakna berbagai konsentrasi ekstrak lidah buaya (Aloe vera L.) dalam menghambat pertumbuhan Candida albicans.

Penelitian Nunung S, dkk (2016) menyebutkan bahwa lidah buaya (Aloe vera L.) mengandung kuinon, saponin, aminoglukosida, lupeol, asam salisilat, tanin, fenol, sulfur, flavonoid dan minyak atsiri yang mampu untuk menghambat pertumbuhan Candida albicans. ${ }^{17}$ Kuinon merupakan penyedia radikal bebas yang stabil. Kuinon dapat membentuk kompleks yang irreversibel dengan gugus nukleofilik asam amino dari protein, sehingga sering menyebabkan protein bakteri menjadi inaktif dan kehilangan fungsinya serta menyebabkan bakteri tersebut tidak dapat tumbuh dalam media yang terdapat ekstrak lidah buaya. Mekanisme antibakteri pada senyawa fenolat terhadap bakteri yaitu senyawa fenol dan turunannya yang dapat mengubah sifat protein sel bakteri. Perubahan struktur protein pada dinding sel bakteri akan meningkatkan permeabilitas sel sehingga pertumbuhan sel akan terhambat dan kemudian sel menjadi rusak. ${ }^{18}$

Menurut Azizah dan Sri (2000), daun lidah buaya (Aloe vera L.) mengandung saponin dan flavonoid. Saponin mempunyai efek sebagai antimikroba, dapat menghambat pertumbuhan jamur, meningkatkan permeabilitas sel mukosa intestin, menghambat transpor aktif makanan dan memudahkan masuknya substansi yang dalam kondisi normal tidak dapat diserap. Saponin mempunyai tingkat toksisitas yang tinggi melawan jamur. Mekanisme kerja saponin sebagai antijamur berhubungan dengan interaksi saponin dengan sterol membran. ${ }^{7}$ Flavonoid merupakan senyawa turunan fenol yang terdapat pada tumbuhan dan larut dalam air. Mekanisme kerja dari flavonoid dalam menghambat pertumbuhan bakteri atau jamur yaitu dengan merusak permeabilitas dinding sel, mikrosom dan lisosom. ${ }^{18}$

\section{KESIMPULAN DAN SARAN}

Berdasarkan hasil penelitian dapat disimpulkan terdapat pengaruh ekstrak lidah buaya (Aloe vera L.) sebagai pembersih gigi tiruan terhadap pengurangan jumlah Candida albicans pada basis gigi tiruan resin akrilik heat cured. Saran dari hasil penelitian ini agar dilakukan penelitian lebih lanjut mengenai konsentrasi lidah buaya sebagai pembersih gigi tiruan yang dapat digunakan oleh masyarakat.

\section{DAFTAR PUSTAKA}

1. David D, Munadziroh E. Perubahan Warna Lempeng Resin Akrilik yang Direndam Dalam Larutan Desinfektan Sodium Hipoklorit Dan Klorhexidin. Dent $J$ (Majalah Kedokt Gigi). 2016;38(1):36.

2. Rahman EF. Efektivitas Ekstrak Daun Dewa (Gynura pseudochina (Lour.) Dc) Terhadap Pertumbuhan Candida Albicans Pada Plat Dasar Gigi Tiruan Resin Akrilik. Fak Kedokt Gigi UNISSULA. 2010;48(123):2.

3. Sundari I, Sofya PA, Hanifa M. Studi Kekuatan Fleksural Antara Resin Akrilik Heat Cured Dan Termoplastik Nilon Setelah Direndam Dalam Minuman Kopi Uleekareng (Coffea Robusta). J Syiah Kuala Dent Soc. 2016;1(1):51-8.

4. Lahama L, Wowor VNS, Waworuntu OA. Angka Kejadian Stomatitis yang Diduga Sebagai Denture Stomatitis Pada Pengguna Gigi Tiruan di Kelurahan Batu Kota Manado. J Ilm Farm. 2015;4(4):71-81.

5. Wahyuningtyas E. Pertumbuhan Candida Albicans Pada Plat Gigi Tiruan Resin Akrilik. Indones J Dent. 2008;15(3):187-91.

6. Mubarak Z, Rahmayani L, Nasution AI, Bunjamin P. Comparison Of Candida Sp. Colonies In Gargling- 
Volume Culture From Subject Wearers Of Heat-Cured And Self-Cured Acrylic Resin Removable Partial Dentures. World J Dent. 2018;8(6):471-74.

7. Huslina F. Pengaruh Ekstrak Lidah Buaya (Aloe Vera L.) Terhadap Pertumbuhan Jamur Candida Albicans Secara In Vitro. J Biot. 2017;5(1):72-7.

8. Nila Farid Moeloek. Formularium Ramuan Obat Tradisional Indonesia. Keputusan Menteri Kesehat Republik Indonesia Nomor Hk0107/ Menkes/187/2017.2017;4:110

9. Mahajan M. Evaluation Of Different Motivational Factors For Seeking Orthodontic Treatment: The Patients' And Parents' Response. J Dent Allied Sci. 2018;7(2):55-9.

10. DP A, Sadimin S, Sariyem S, Nugraheni H. Daya Hambat Getah Lidah Buaya (Aloe Vera) Terhadap Pertumbuhan Bakteri Streptococcus Mutans. J Kesehat Gigi. 2015;02(1):1-7.

11. Viona Diansari, Sri Fitriyani FMH. Studi Pelepasan Monomer Sisa Dari Resin Akrilik Heat Cured Setelah Perendaman Dalam Akuades. Cakradonya Dent J 2016; 8(1)1-76. 2013;84(1):487-92.

12. Sri Rezeki, Santi Chismirina AI. Pengaruh Ekstrak Daun Sirih Merah (Piper Crocatum) Terhadap Pertumbuhan Candida Albicans. J Syiah Kuala Dent Soc. 2018;2(1):52-62.
13. Novi Yanti, Samingan Samingan MM. Uji Aktivitas Antifungi Ekstrak Etanol Gal Manjakani (Quercus Infectoria) Terhadap Candida Albicans. J Ilm Mhs Pendidik Biol. 2016;1(1):1-9.

14. Dahar E, Chandra D. Jumlah Candida Albicans Pada Bahan Basis Gigi Tiruan Resin Akrilik Polimerisasi Panas Yang Dipoles Dan Tidak Dipoles. Dentika Dent J. 2014;18(1):75-9.

15. Hamrun N, Mahardhika A. Jumlah Koloni Candida Albicans Pada Pemakai Gigi Tiruan Penuh Berdasarkan Lama Pemakaian. Fak Kedokt Gigi Univ Hasanuddin. 2014;3(3):1-4.

16. Rahayu I, Fadriyanti O, Edrizal. Efektivitas Pembersih Gigi Tiruan Dengan Rebusan Daun Lempeng Resin Akrilik Polimerisasi Panas. J B-Dent. 2014;1(2):142-9.

17. Mukhriani. Ekstraksi Pemisahan Senyawa dan Identifikasi Senyawa Aktif. J Kesehat. 2014;VII(2):361-7.

18. Nunung Sulistyani, Eni Kurniati, Yakup dan RAC. Aktivitas Antibakteri Infusa Daun Lidah Buaya (Aloe barbadensis Miller). J Penelit Saintek. 2016;21(2):12 